\section{VILNIUS TECH}

Vilniaus Gedimino technikos universitetas 24-osios Lietuvos jaunujų mokslininkų konferencijos „Mokslas - Lietuvos ateitis“ teminè konferencija Proceedings of the 24th Conference for Junior Researchers "Science - Future of Lithuania"

\section{APLINKOS APSAUGOS INŽINERIJA / ENVIRONMENTAL PROTECTION ENGINEERING}

2021 m. kovo 19 d. Vilnius, Lietuva

19 March 2021, Vilnius, Lithuania

ISSN 2029-7157

elSSN 2029-7149

ISBN 978-609-476-270-3

eISBN 978-609-476-271-0

http://jmk.aainz.vgtu.It

https://doi.org/10.3846/aainz.2021.20

\title{
NEAPDOROTŲ PADANGŲ TEKSTILĖS PLUOŠTO ATLIEKŲ GARSO SUGERTIES TYRIMAI
}

\author{
Robert Ružickij ${ }^{1}$, Raimondas Grubliauskas ${ }^{2}$ \\ Vilniaus Gedimino technikos universitetas, Aplinkos inžinerijos fakultetas, \\ Aplinkos apsaugos ir vandens inžinerijos katedra \\ El.p. ${ }^{1}$ robert.ruzickij@vilniustech.lt; ${ }^{2}$ raimondas.grubliauskas@vilniustech.lt
}

\begin{abstract}
Anotacija. Perdirbant padangas, gumos granulès ir metalo pluoštas sèkmingai naudojami pakartotinai, tačiau padangų tekstilès pluošto (PTP) atliekos yra gana didelè problema. Mokslininkai vykdo tyrimus, bandydami šias padangų tekstilès pluošto atliekas, naudoti šiluminei izoliacijai, nes čia matomas didelis jų potencialas. Kadangi šiluminè izoliacija turi artimą ryši su garso sugertimi, manoma, kad PTP sẻkmingai tiktų panaudoti ir triukšmui patalpose mažinti. Tyrimo metodas remiasi ISO 10534-2 standartu, kuriuo būtų nustatytas medžiagos garso sugerties koeficientas $\alpha$ naudojant impedanso vamzdị. Tyrimo metu gauti rezultatai parodè, kad PTP atliekos turi geras garso sugerties savybes, garso sugerties koeficientas, esant žemiems dažniams $250-500 \mathrm{~Hz}$, buvo 0,06-0,52, o esant aukštesniems dažniams - 1000-1600 Hz, sugerties koeficientas varijavo tarp $0,44-0,94$. Šios medžiagos naudojimas būtų puiki alternatyva šiuo metu naudojamoms tradicinėms mineralinėms pluoštinèms medžiagoms.
\end{abstract}

Reikšminiai žodžiai: garso sugerties koeficientas, padangų atliekos, pluoštinės garsą sugeriančios medžiagos.

\section{Ivadas}

Triukšmas modernioje visuomeneje tampa vis aktualesne ir svarbesne tema. $2020 \mathrm{~m}$. Europos aplinkos agentūros išleistoje ataskaitoje teigiama, kad apie $130 \mathrm{mln}$. Europos Sajungos šalių narių piliečių yra veikiami didesnio nei 55 dBA triukšmo, kai rekomenduotinas paros vidurkis $L_{D V N}$ yra mažesnis nei $55 \mathrm{dBA}$ (European Environment Agency, 2020). Pagrindiniai triukšmo šaltiniai yra kelių, geležinkelių ir oro transportas (Murphy et al., 2020). Skaičiai pastaruoju metu išlieka stabilūs, tačiau situacija vis dar mažai sprendžiama, nors ir buvo iškelti tikslai smarkiai sumažinti triukšmą aplinkoje (European Environment Agency, 2017). Triukšmui mažinti galima pasitelkti ịvairių būdų, vienas iš jų - garsą sugeriančios medžiagos.

Padangų tekstilès pluoštas (PTP) (1 pav.) - tai atliekos, susidariusios po padangu perdirbimo. Padangu perdirbimas yra sudètingas procesas, nes reikia atskirti komponentus, kurie ịkomponuoti i gumos apvalkalą. Pagrindinès padangos sudedamosios dalys yra guma / elastomerai (45-47\%), juodoji anglis (21,5-22\%), metalai (12-25\%), tekstile (0-10\%), cinko oksidas (1-2\%), siera $(1 \%)$, priedai $(5-7,5 \%)$ (Sebola et al., 2018). Kas- met Europoje susidaro apie 3,4 mln. t naudotu padangu atliekų, iš kurių 320 tūkst. t - PTP atliekų (Gigli et al., 2019). Europos Sajungos sąvartynų direktyvoje 1999/31/EC nurodyta, kad padangų atliekas draudžiama laidoti sąvartynuose, todèl būtina jas perdirbti ir naudoti iš naujo. Šiame moksliniame straipsnyje bus sprendžiama PTP atliekų problema, naudojant jas kaip garsą sugeriančią medžiagą.

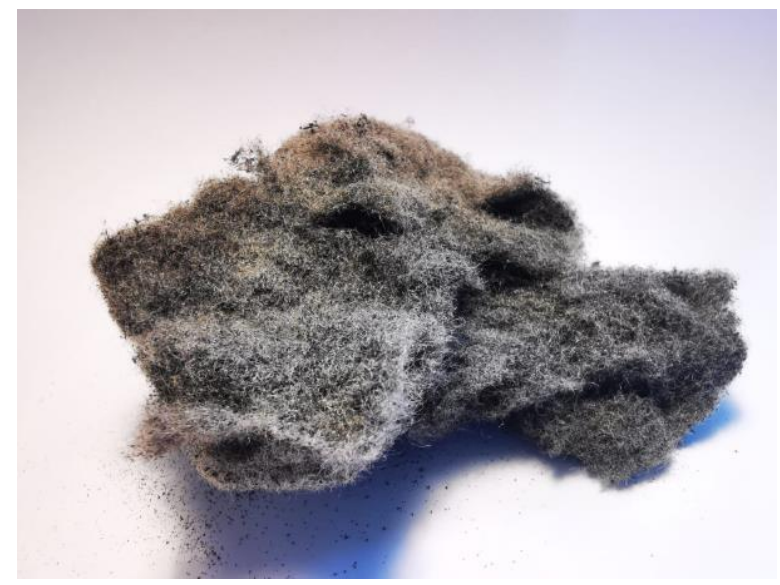

1 paveikslas. Padangų tekstilès pluoštas, gaunamas iš perdirbimo gamyklos

(C) 2021 Robert Ružickij, Raimondas Grubliauskas. Leidejas Vilniaus Gedimino technikos universitetas. Šis straipsnis yra atvirosios prieigos straipsnis, turintis Kūrybinių bendrijų (Creative Commons) licenciją (CC BY 4.0), kuri leidžia neribotą straipsnio ar jo dalių panaudą su privaloma sąlyga nurodyti autorių ir pirminị šaltinị. 
Pastaruoju metu keliami klausimai dèl PTP atliekų pakartotino naudojimo tiek Europos Sajungoje, tiek tarptautiniu mastu. Kadangi padangų nebegalima šalinti sąvartynuose, jos perdirbamos. Guma ir metalai pakartotinai naudojami, bet PTP atliekų naudojimas iki šiol kelia daug problemų (Landi et al., 2018).

Remiantis pastaruoju metu atliktais moksliniais tyrimais, PTP atliekas bandyta panaudoti keliuose pramonès sektoriuose bei igyvendinant inžinerinius sprendinius:

- Gruntui sutvirtinti. Teigiama, kad pridedant nedidelius kiekius PTP atliekų i molinguosius ir smèlinguosius gruntus, ivvairios mechaninès jègos padidèja (Abbaspour et al., 2019; Narani et al., 2020; Zare et al., 2020);

- Betono gamyboje. Atliekant tyrimus buvo nustatyta, kad PTP atliekos nepagerina mechaninių betono savybių, bet sumažina gaminio šiluminị laidumą (Malaiškienè et al., 2015; Baričević et al., 2018).

- Asfalto gamyboje. Nustatyta, kad PTP atlieku naudojimas leistų sutaupyti didelị kieki bitumo, naudojamo kelių statyboje, nes PTP atliekų savybès nėra prastenès už tradicines medžiagas. Mechaninès jègos, naudojant PTP atliekas, padideja apie 6-7 kartus (Landi et al., 2018).

- Garso absorberio gamyboje. Atlikti moksliniai tyrimai parodè, kad PTP atliekos gali būti panaudotos garso sugerčiai, teigiama, kad tiek žemųjų, tiek aukštųjų dažnių juostose gali būti gaunami geri rezultatai (Maderuelo-Sanz et al., 2011).

Taigi, norint išspręsti šių atliekų aplinkai keliamą taršos problemą, PTP atliekas bandoma naudoti kuo plačiau ir ịvairiau. Pvz., šiuo metu vykdomi tyrimai užsienyje, siekiant naudoti PTP atliekas šiluminei izoliacijai. Be kita ko, didžioji dalis tyrimų, apimančių PTP naudojimą, yra susijusi su statybų sektoriumi (Landi et al., 2018).

Akivaizdu, kad PTP atliekos yra mažai ištyrinètos akustiniu aspektu. Tačiau joms daug dèmesio skiriama statybos sektoriuje, pvz., betono ir asfalto gamybos metu buvo atlikti tyrimai, kaip šias atliekas naudoti šiluminei izoliacijai. Šiame darbe kreipiamas dèmesys i neapdorotų PTP atliekų garso sugerties savybes. Šio darbo tikslas - charakterizuoti PTP atliekų garso sugerties koeficientą, keičiant medžiagos tanki ( $t=$ const) ir keičiant medžiagos stori $(\rho=$ const $)$. Tyrimai atlikti pritaikant standartini perdavimo funkcijos metodą su dviejų mikrofonų impedanso vamzdžio sistema. Re- zultatai, gauti šiame darbe, bus naudojami tolesniems PTP atliekų tyrimams.

Darbą sudaro: tyrimo metodika, rezultatai ir diskusija bei bendrosios išvados.

\section{Metodika}

Eksperimentiniams tyrimams buvo naudotos neapdorotos PTP atliekos. Perdirbant padangas, PTP atliekos yra atskiriamos nuo gumos bei metalų ir yra surenkamos i maišus ir sandèliuojamos. PTP atliekos buvo džiovinamos džiovyklèje, $80{ }^{\circ} \mathrm{C}$ temperatūroje, siekiant pašalinti drègmę. Visas džiovinimo procesas truko tris dienas.

Bandiniui suformuoti ir tirti buvo atspausdinti laikikliai (2 pav.). Laikiklių išoriniai matmenys buvo $98 \times 98 \mathrm{~mm}$, aukštis - $10 \mathrm{~mm}$, sienučių storis - $2 \mathrm{~mm}$. Naudojantis šiais laikikliais galima išgauti skirtingo storio bandinius, t. y. sudedant kelis $10 \mathrm{~mm}$ storio laikiklius paeiliui.

Siekiant užtikrinti, kad bandinys būtų stabilus, jis buvo sutvirtintas 20 ir $40 \mathrm{~mm}$ storio laikikliais.

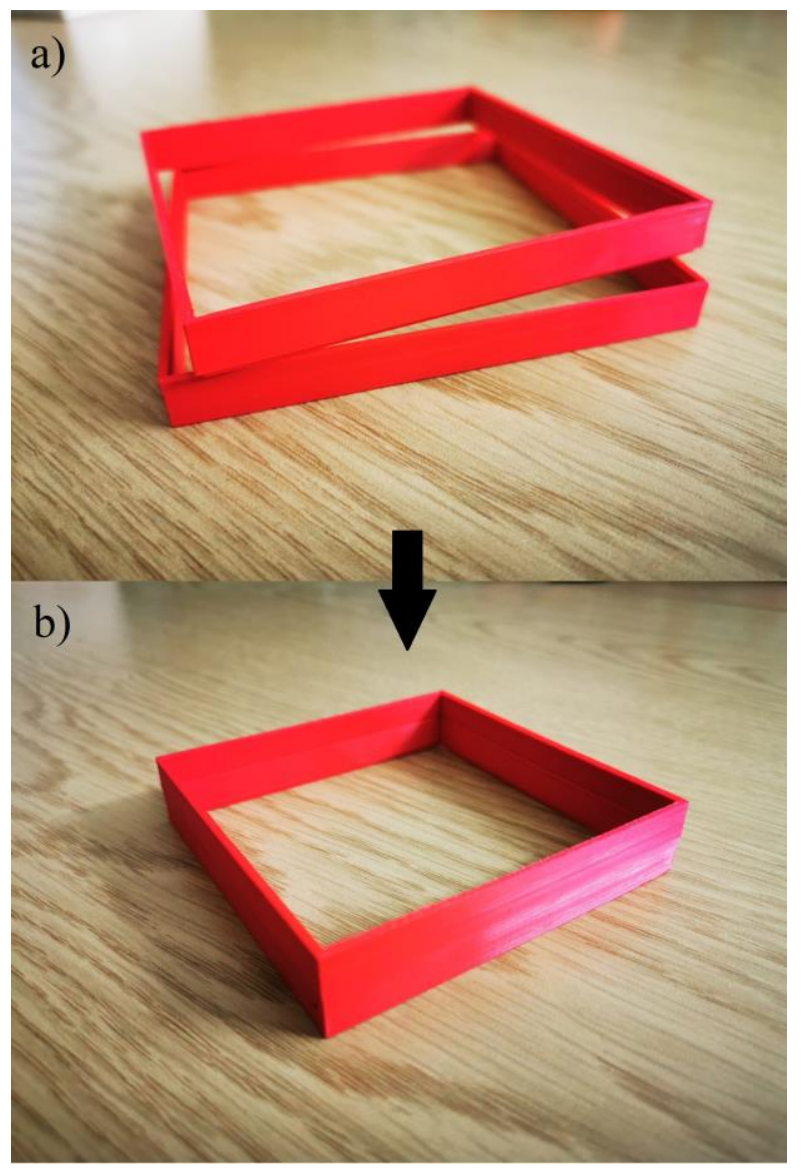

2 paveikslas. Laikikliai, išspausdinti 3D spausdintuvu, bandiniui suformuoti: a - atskiri laikikliai, kuriuos galima kombinuoti; $\mathrm{b}$ - sukombinuoti du laikikliai 


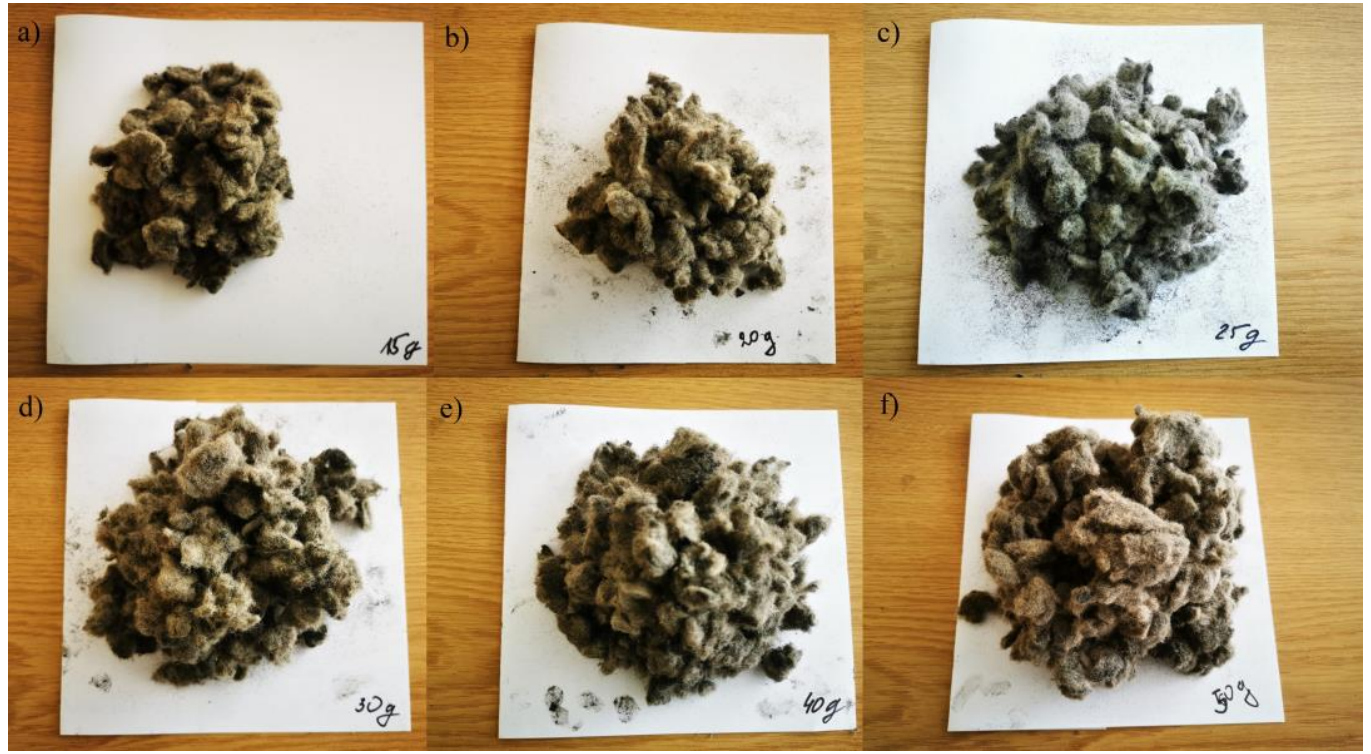

3 paveikslas. Skirtingo tankio bandiniai garso sugerties tyrimams: a ir d $-75 \mathrm{~kg} / \mathrm{m}^{3}$; b ir e $-100 \mathrm{~kg} / \mathrm{m}^{3}$; c ir f $-125 \mathrm{~kg} / \mathrm{m}^{3}$

Garso sugerties tyrimams buvo pasirinktos tokios PTP atliekų tankio ir storio kombinacijos (3 pav.):

- $20 \mathrm{~mm}$ storio ir 75,100 ir $125 \mathrm{~kg} / \mathrm{m}^{3}$ tankio bandiniai;

- $40 \mathrm{~mm}$ storio ir 75,100 ir $125 \mathrm{~kg} / \mathrm{m}^{3}$ tankio bandiniai.

Atitinkamai masè, kuri turètų būti įdèta ị laikiklị, buvo apskaičiuota pagal proporcijas. Žinant laikiklio tūrị, galima apskaičiuoti masę, reikalingą numatytam tankiui pasiekti. Tyrimo metu buvo ieškoma priklausomybė nuo medžiagos storio ( $\rho=$ const, $t$ kito) bei priklausomybè nuo tankio ( $t=$ const, $\rho$ kito) (4 pav.).

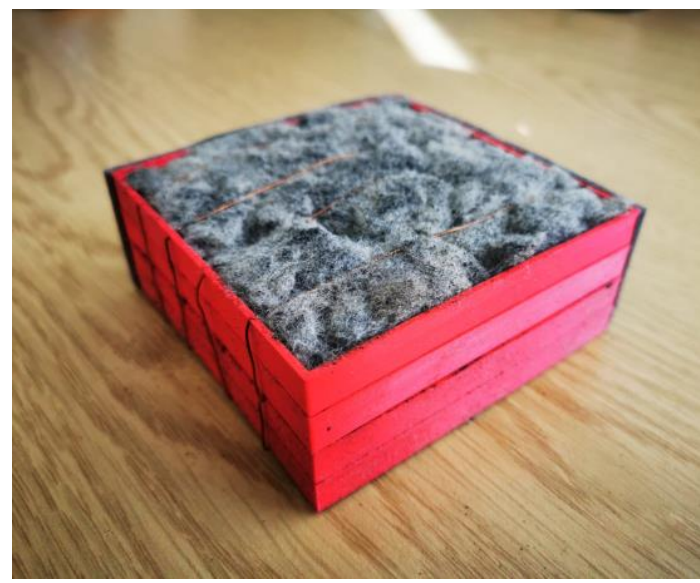

4 paveikslas. Laikiklis, pripildytas bandomosios medžiagos

PTP atliekų garso sugerties nustatymo metodas remiasi ISO 10534-2 standartu (International Organization for Standardization [ISO], 1998). Garso sugerties koefi- cientui $\alpha$ nustatyti buvo naudojamas įrenginys - impedanso vamzdis. Impedanso vamzdis (5 pav.) - įrenginys, naudojamas medžiagų garso sugerties ir garso atspindžiui nustatyti, kai banga juda link bandinio. Impedanso vamzdis yra gaminamas iš metalo arba organinio stiklo. Pagrindinès sudedamosios dalys yra kietas korpusas, garso šaltinis, mikrofonai ir kietas standus paviršius. Naudojantis impedanso vamzdžiu netiesioginiu metodu galima nustatyti medžiagų neakustinius parametrus - porètumą, poros lenktumą ir oro pasipriešinimą (Umnova et al., 2005; Doutres et al., 2010).

Impedanso vamzdžio vidiniai matmenys yra $100 \times 100 \mathrm{~mm}$, todèl bandinys turèjo būti šiek tiek mažesnis, kad tilptų i bandymo ịrangą. Bandinys buvo pristumtas prie kieto standaus paviršiaus ir užsandarintas, naudojant ličio tepalą, kad būtų išvengta garso nuotékio. Atstumas tarp mikrofono Nr. 1 ir bandinio buvo $x_{1}-190 \mathrm{~mm}$, o mikrofono Nr. 2 ir bandinio $x_{2}-$ $100 \mathrm{~mm}$, atstumas tarp mikrofono Nr. 1 ir Nr. 2 sudarè $s-90 \mathrm{~mm}$.

Impedanso vamzdžio darbiniai dažniai yra nuo 200 iki 1600 Hz, kurie leidžia nustatyti garso sugertị žemujjųvidutinių dažnių juostose. Šie dažniai yra aktualūs akustikos inžinerijos srityje. Rezultatai pateikiami 1/3 oktavos dažnių juostoje.

ISO 10534-2 apibūdina perdavimo funkcijos metodą, kurio pagrindu atliekami matavimai. Impedanso vamzdic sudaro dviejų mikrofonų sistema. Perdavimo funkcija $H_{12}$ (1 formulè) apskaičiuojama kaip išmatuoto slègio santykis tarp antrojo ir pirmojo mikrofonų. 


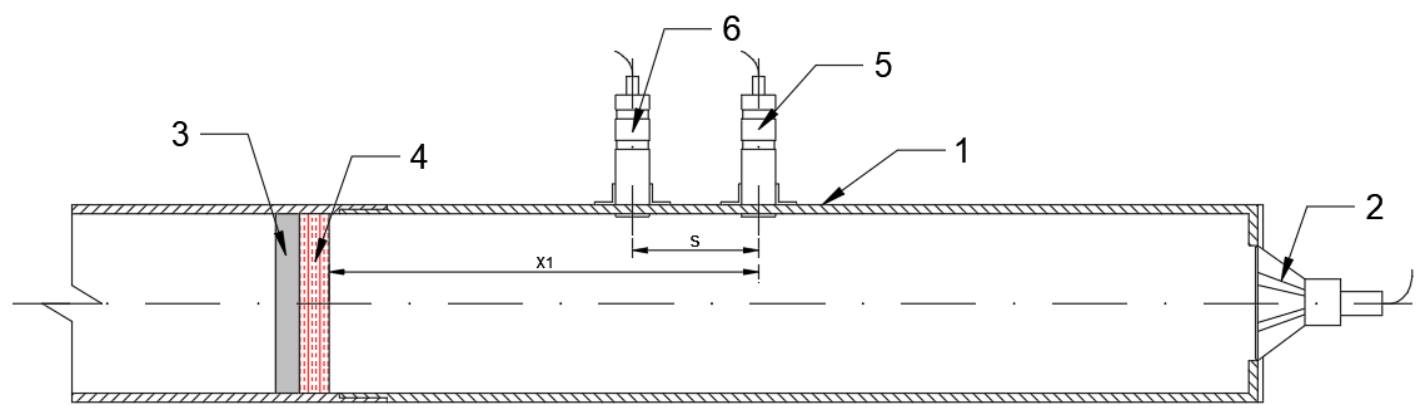

5 paveikslas. Impedanso vamzdžio sistema, naudota tyrimams: 1 - kietas korpusas; 2 - garso šaltinis; 3 - kietas standus paviršius; 4 - bandinio vieta; 5 - pirmasis mikrofonas; 6 - antrasis mikrofonas

$$
H_{12}=\frac{p_{2(f)}}{p_{1(f)}}
$$

Krintančios bangos perdavimo funkcija apskaičiuojama pagal 2 formulę (ISO, 1998):

$$
H_{I}=e^{-j k_{0} s} \text {. }
$$

Atsispindejjusios bangos perdavimo funkcija apskaičiuojama pagal 3 formulę (ISO, 1998):

$$
H_{R}=e^{j k_{0} s} .
$$

Iš 1,2 ir 3 formulès garso atspindžio koeficientas gali būti apskaičiuojamas pagal tokią formulę:

$$
R=\frac{H_{12}-H_{I}}{H_{R}-H_{12}} e^{2 j k_{0} x_{1}} .
$$

Garso sugerties koeficientas yra atvirkščias dydis garso atspindžiui, todèl galima apskaičiuoti pagal šią formulę:

$$
\alpha=1-|R|^{2} .
$$

Garso sugerties parametras yra bedimensis dydis ir varijuoja tarp 0 ir 1 . Duomenų apdorojimui buvo naudotas MATLAB kodas.

\section{Rezultatai ir diskusija}

Pritaikius aprašytą metodą, eksperimentinių tyrimų metu buvo išanalizuoti šeši skirtingi bandiniai. Pirmuoju atveju buvo tirta situacija, kai storis buvo pastovus $(\mathrm{t}=$ const $)$, o tankis kito, t. y. didejjo. 6 pav. pateikti pirmojo bandymo rezultatai.

Iš rezultatų galima matyti, kad, didinant tankị ir atitinkamai didejjant dažniui, dideja ir garso sugerties koeficientas. Geriausią rezultatą parode bandinys, kurio tankis buvo $125 \mathrm{~kg} / \mathrm{m}^{3}$. Bandiniu $75 \mathrm{~kg} / \mathrm{m}^{3}$ ir $100 \mathrm{~kg} / \mathrm{m}^{3}$ rezultatai iki $400 \mathrm{~Hz}$ dažnio buvo vienodi, tačiau didèjant dažniui tankesnè medžiaga parodè geresnius rezultatus, kai esant $500 \mathrm{~Hz} 75 \mathrm{~kg} / \mathrm{m}^{3}$ garso sugerties koeficientas buvo
$0,15, \quad$ o $\quad 100 \mathrm{~kg} / \mathrm{m}^{3}-\quad 0,18$. Tankesnio bandinio $\left(125 \mathrm{~kg} / \mathrm{m}^{3}\right)$ garso sugertis nuo žemujų dažnių buvo didesnè nei pastarujų, esant $250 \mathrm{~Hz}$ dažniui, $125 \mathrm{~kg} / \mathrm{m}^{3}$ garso sugerties koeficientas buvo 0,05 daugiau $(0,11 \pm 0,03)$. Esant $1600 \mathrm{~Hz}$ dažniui, $75 \mathrm{~kg} / \mathrm{m}^{3}$ bandinio garso sugerties rezultatas buvo $0,69,100 \mathrm{~kg} / \mathrm{m}^{3}-0,76, \mathrm{o}$ $125 \mathrm{~kg} / \mathrm{m}^{3}-0,82$.

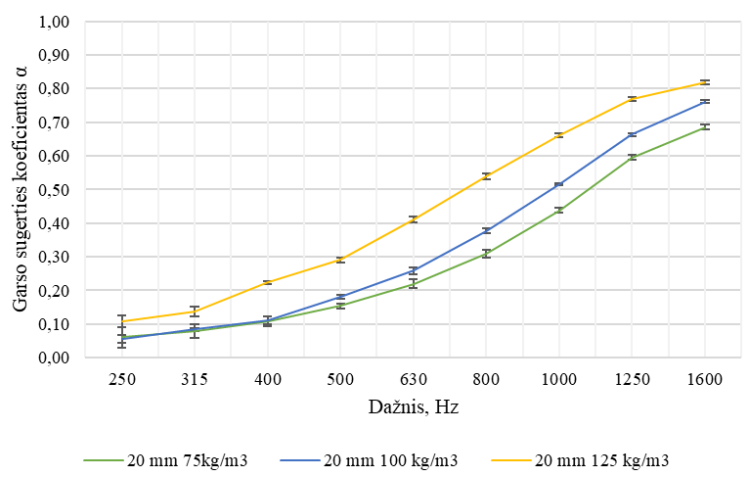

6 paveikslas. Garso sugerties rezultatai, kai bandinio storis $20 \mathrm{~mm}$, o tankis didèjo nuo $75 \mathrm{iki} 125 \mathrm{~kg} / \mathrm{m}^{3}$

7 pav. pateikiami kito bandinio rezultatai. Šiuo atveju buvo padidintas storis iki $40 \mathrm{~mm}$, siekiant patikrinti, ar garso sugerties koeficientas didejja, esant žemiesiems dažniams. Yra žinoma, kad norint, jog būtu gera garso sugertis, reikia, kad bandinio storis būtų ne mažesnis nei $1 / 4$ bangos ilgio. Tankiai buvo parinkti tokie patys, t. y. 75 , 100 ir $125 \mathrm{~kg} / \mathrm{m}^{3}$.

Iš rezultatu galima matyti, kad padidinus bandinio storị ir išlaikius tuos pačius tankio dydžius, garso sugerties rezultatai, esant žemiesiems dažniams, padidejo. Lyginant su $20 \mathrm{~mm}$ storio bandiniu, esant $250 \mathrm{~Hz}$ dažniui, garso sugerties rezultatai padidèjo apie 2 kartus - vidutiniškai nuo $0,08 \pm 0,01$ iki $0,20 \pm 0,01$.

Tačiau, lyginant su $20 \mathrm{~mm}$ storio bandiniu, čia matomas atvirkščias efektas, kai didinant tankị garso sugertis didejja tik iki tam tikros ribos, šiuo atveju iki $630 \mathrm{~Hz}$, o vèliau didèjimas nebèra staigus. 


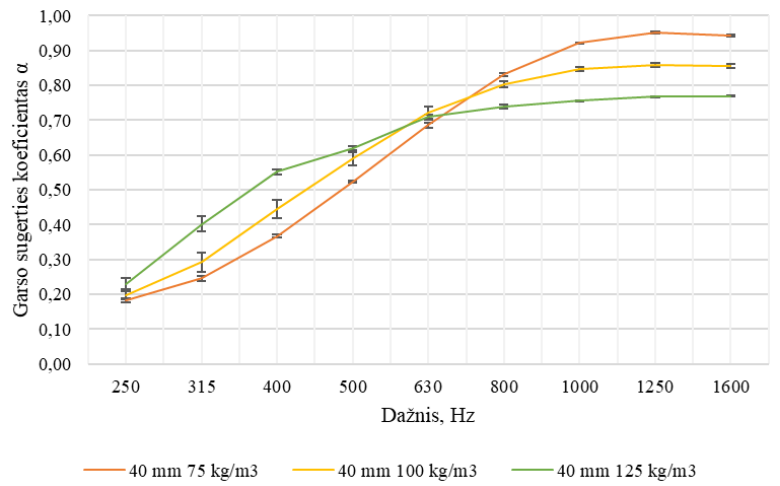

7 paveikslas. Garso sugerties rezultatai, kai bandinio storis $40 \mathrm{~mm}$, o tankis didèjo nuo $75 \mathrm{iki} 125 \mathrm{~kg} / \mathrm{m}^{3}$

Visų trijų bandinių garso sugerties koeficientas buvo apie $0,70 \pm 0,01$ esant $630 \mathrm{~Hz}$. Esant žemiesiems dažniams, nuo 250 iki $630 \mathrm{~Hz}$ geriausia garso sugertis buvo $125 \mathrm{~kg} / \mathrm{m}^{3}$ bandinio, rezultatas buvo nuo $0,23 \pm 0,02$ iki $0,71 \pm 0,01$. Esant $1600 \mathrm{~Hz}$ dažniui, geriausias garso sugerties koeficientas buvo pasiektas $75 \mathrm{~kg} / \mathrm{m}^{3}$ bandinio ir rezultatas buvo 0,94 . Prastesnis rezultatas buvo pasiektas $100 \mathrm{~kg} / \mathrm{m}^{3}-0,85$, o prasčiausias $125 \mathrm{~kg} / \mathrm{m}^{3}-0,77$. Tokią tendenciją galima matyti, nes, padidèjus bandinio storiui, padidejo ir aerodinaminis pasipriešinimas, o tai lèmè, kad garso banga nebegali prasiskverbti ị medžiagą giliau, todèl gilesnès medžiagos poros tampa neefektyvios ir garso sugertis nedidèja (Stauskis, 2007).



8 paveikslas. Garso sugerties rezultatai, kai bandinio tankis buvo $75 \mathrm{~kg} / \mathrm{m}^{3}$, o storis kito nuo 20 iki $40 \mathrm{~mm}$

Antrojoje tyrimo dalyje buvo tiriamas atvejis, kai tankis buvo pastovus ( $\rho=$ const), o bandinio storis kito nuo 20 iki $40 \mathrm{~mm}$. Pirmuoju atveju buvo tirtas $75 \mathrm{~kg} / \mathrm{m}^{3}$ bandinys. 8 pav. pateikiami tyrimo rezultatai.

Remiantis gautais rezultatais galima matyti, kad išlaikant tą patị tankị, bet padidinant medžiagos storị, garso sugerties koeficientas padideja. Lyginant rezultatus 250
$630 \mathrm{~Hz}$ dažnių juostose, padidinus storị dvigubai, garso sugerties koeficientas padidejjo 3 kartus. Didžiausias garso sugerties skirtumas matomas $800 \mathrm{~Hz}$ dažnyje, kur skirtumas buvo $0,52.1600 \mathrm{~Hz}$ dažnyje, esant $20 \mathrm{~mm}$ storiui, garso sugerties koeficientas buvo 0,69 , o, esant $40 \mathrm{~mm}$ storiui, sugertis buvo 0,94 . Todèl galima teigti, kad esant $75 \mathrm{~kg} / \mathrm{m}^{3}$ tankiui geriausia garso sugerčiai naudoti $40 \mathrm{~mm}$ storio medžiagą. Kaip buvo minèta, storesnè medžiaga yra efektyvesnè garso sugerčiai.

9 pav. pateikiami rezultatai, kai tankis buvo $100 \mathrm{~kg} / \mathrm{m}^{3}$.

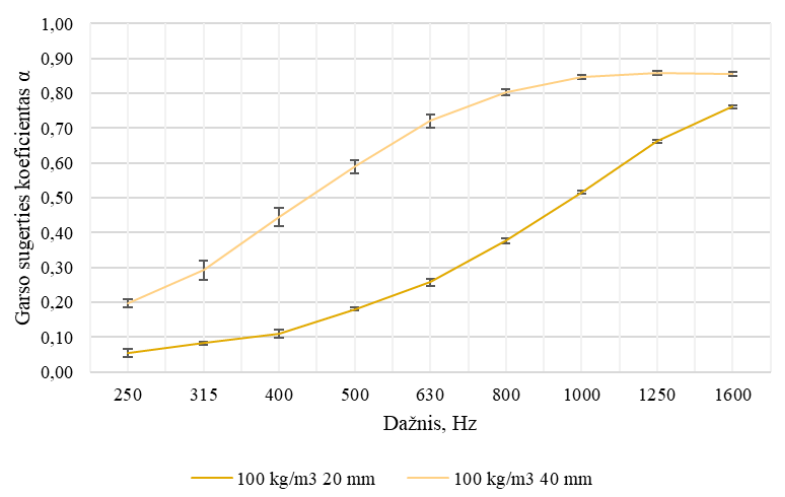

9 paveikslas. Garso sugerties rezultatai, kai bandinio tankis $100 \mathrm{~kg} / \mathrm{m}^{3}$, o storis kito nuo 20 iki $40 \mathrm{~mm}$

Šioje situacijoje taip pat matomas trigubas garso sugerties padidejimas, kai medžiagos storis padideja 2 kartus. Garso sugertis $20 \mathrm{~mm}$ bandinyje, esant $250 \mathrm{~Hz}$ buvo 0,06 , o $40 \mathrm{~mm}$ mèginio - 0,20 . Didžiausias garso sugerties skirtumas stebimas esant $630 \mathrm{~Hz}$ dažniui. Iš paveikslo matyti, kad $40 \mathrm{~mm}$ bandinys yra efektyvesnis žemesniujų dažnių atvejais. Esant $1600 \mathrm{~Hz}, 20 \mathrm{~mm}$ mèginio garso sugerties koeficientas buvo 0,76 , o $40 \mathrm{~mm}-$ 0,85 . Palyginus su $75 \mathrm{~kg} / \mathrm{m}^{3}$ bandiniu, tankesnis bandinys efektyvesnis iki $630 \mathrm{~Hz}$, toliau garso sugertis yra mažesnè.

10 pav. pavaizduoti paskutinio tyrimo rezultatai, šiuo atveju lyginant $125 \mathrm{~kg} / \mathrm{m}^{3}$ bandinius, kurių storiai buvo 20 ir $40 \mathrm{~mm}$.

Iš pateiktų rezultatu galima matyti panašią tendenciją, kaip ir prieš tai dviejuose buvusiuose bandiniuose. $40 \mathrm{~mm}$ bandinys yra efektyvesnis garso sugerčiai, tačiau drastiško skirtumo nèra. Pastebima, kad esant $1250 \mathrm{~Hz}$, $40 \mathrm{~mm}$ bandinys praranda pranašumą prieš $20 \mathrm{~mm}$ bandinị. $20 \mathrm{~mm}$ bandinio garso sugertis, esant $1600 \mathrm{~Hz}$, buvo 0,82 , o $40 \mathrm{~mm}$ bandinio - 0,77 . Dèl to padidejęs aerodinaminis pasipriešinimas nebeleido garso bangai pasiekti gilesnių bandinio sluoksnių. 


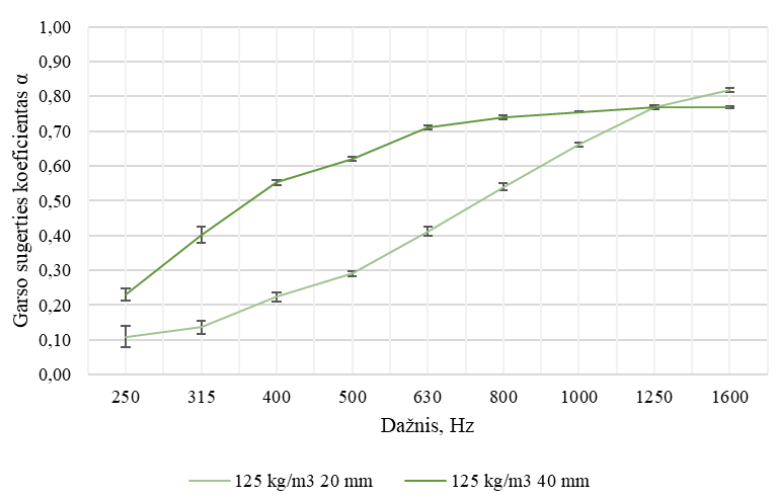

10 paveikslas. Garso sugerties rezultatai, kai bandinio tankis $125 \mathrm{~kg} / \mathrm{m}^{3}$, o storis kito nuo 20 iki $40 \mathrm{~mm}$

Tyrimų metu gauti rezultatai parodè, kad, didinant medžiagos tankị ir storị, garso sugertis didejja. Būtų verta praplèsti tyrimus ir išanalizuoti didesnę bandinių storių ir tankių ịvairovę, pvz., kokia būtų garso sugertis, jei tankị dar labiau sumažintume arba dar labiau padidintume, ar būtų stebima tokia pati tendencija, kai, esant didesniam storiui, garso sugertis, didejjant tankiui, nuo tam tikrų dažnių taip intensyviai nebekyla. Taip pat būtų verta išanalizuoti medžiagą, esant kitiems dažniams, nei buvo atlikti šie tyrimai. Lyginant PTP atliekų garso sugertị su tradicinėmis pluoštinèmis medžiagomis, matyti, kad garso sugerties efektyvumas yra labai panašus $-\alpha$ koeficientas varijuoja tarp 0,25-0,93 (Ružickij et al., 2020).

\section{Išvados}

1. Atlikus eksperimentinius tyrimus, kai medžiagos storis buvo $20 \mathrm{~mm}$, o tankis didèjo nuo $75 \mathrm{iki} 125 \mathrm{~kg} / \mathrm{m}^{3}$, garso sugertis didèjo su tankiu. Esant $1600 \mathrm{~Hz}, 125 \mathrm{~kg} / \mathrm{m}^{3}$ bandinio garso sugerties koeficientas buvo 0,82 , $100 \mathrm{~kg} / \mathrm{m}^{3}-0,76$, o $75 \mathrm{~kg} / \mathrm{m}^{3}-0,69$.

2. Išanalizavus $40 \mathrm{~mm}$ storio bandinị, buvo matoma tendencija, kad tankesnès medžiagos garso sugertis buvo didesnè iki $630 \mathrm{~Hz}$, tačiau vèliau $75 \mathrm{~kg} / \mathrm{m}^{3}$ bandinio garso sugertis buvo didesnè. Esant $1600 \mathrm{~Hz}$ dažniui, $75 \mathrm{~kg} / \mathrm{m}^{3}$ garso sugertis buvo $0,94,100 \mathrm{~kg} / \mathrm{m}^{3}-0,85$, o $125 \mathrm{~kg} / \mathrm{m}^{3}-0,77$. Nedidèjančią garso sugerti lèmè padidèjęs aerodinaminis pasipriešinimas.

3. Palyginus medžiagas, kai tankis išliko pastovus, o bandinio storis keitèsi, storesnè medžiaga (40 mm) iki $630 \mathrm{~Hz}$ buvo 3 kartus efektyvesnè nei $20 \mathrm{~mm}$ bandinys, tai nustatyta atliekant visus tris palyginimus.

\section{Literatūra}

Abbaspour, M., Aflaki, E., \& Moghadas Nejad, F. (2019). Reuse of waste tire textile fibers as soil reinforcement. Journal of Cleaner Production, 207, 1059-1071. https://doi.org/10.1016/j.jclepro.2018.09.253

Baričević, A. Jelčić Rukavina, M., Pezer, M., \& Štirmer, N. (2018). Influence of recycled tire polymer fibers on concrete properties. Cement and Concrete Composites, 91, 29-41.

https://doi.org/10.1016/j.cemconcomp.2018.04.009

Doutres, O., Salissou, Y., Atalla, N., \& Panneton, R. (2010). Evaluation of the acoustic and non-acoustic properties of sound absorbing materials using a three-microphone impedance tube. Applied Acoustics, 71(6), 506-509. https://doi.org/10.1016/j.apacoust.2010.01.007

European Environment Agency. (2017). Environmental indicator report 2017. In support to the monitoring of the $7^{\text {th }}$ Environment Action Programme. EEA Report, No. 21. https://www.eea.europa.eu/publications/environmentalindicator-report-2017

European Environment Agency. (2020). Environmental noise in Europe - 2020 (EEA Report, No. 22).

https://www.eea.europa.eu/publications/environmentalnoise-in-europe

Gigli, S., Landi, D., \& Germani, M. (2019). Cost-benefit analysis of a circular economy project: A study on a recycling system for end-of-life tyres. Journal of Cleaner Production, 229, 680-694.

https://doi.org/10.1016/j.jclepro.2019.03.223

International Organization for Standardization. (1998). Acoustics - Determination of sound absorption coefficient and impedance in impedance tubes. Part 2: Transferfunction method (ISO 10534-2:1998). Geneve. https://www.iso.org/standard/22851.html

Landi, D., Marconi, M., Meo, I., \& Germani, M. (2018). Reuse scenarios of tires textile fibers: An environmental evaluation. In Procedia Manufacturing, 21, 329-336. https://doi.org/10.1016/j.promfg.2018.02.128

Maderuelo-Sanz, R., Nadal-Gisbert, A. V., Crespo-Amorós, J. E., \& Parres-García, F. (2011). A novel sound absorber with recycled fibers coming from end of life tires (ELTs). Applied Acoustics, 73(4), 402-408. https://doi.org/10.1016/j.apacoust.2011.12.001

Malaiškienė, J., Nagrockienė, D., \& Skripkiūnas, G. (2015). Possibilities to use textile cord waste from used tires for concrete. Journal of Environmental Engineering and Landscape Management, 23(3), 183-191. https://doi.org/10.3846/16486897.2015.1057514

Murphy, E., Faulkner, J. P., \& Douglas, O. (2020). Current state-of-the-art and new directions in strategic environmental noise mapping. Current Pollution Reports, 6, 54-64. https://doi.org/10.1007/s40726-020-00141-9

Narani, S. S., Abbaspour, M., Mir Mohammad Hosseini, S. M., \& Moghadas Nejad, F. (2020). Long-term dynamic behavior of a sandy subgrade reinforced by Waste Tire Textile Fibers (WTTFs). Transportation Geotechnics, 24, 100375. https://doi.org/10.1016/j.trgeo.2020.100375 
Ružickij, R., Astrauskas, T., Valtere, S., \& Grubliauskas, R. (2020). Sound absorption properties evaluation and analysis of recycled tyre textile fibre waste. Environmental and Climate Technologies, 24(3), 318328. https://doi.org/10.2478/rtuect-2020-0106

Sebola, M. R., Mativenga, P. T., \& Pretorius, J. (2018). A benchmark study of waste tyre recycling in South Africa to European Union practice. Procedia CIRP, 69, 950-955. https://doi.org/10.1016/j.procir.2017.11.137

Stauskis, V. J. (2007). Statybinè akustika (2-oji pataisyta laida). Technika.

https://leidykla.vgtu.1t/index.php?id_product=251\&id_pro duct_attribute $=0 \&$ rewrite $=$ statybine-

akustika\&controller=product\&id_lang=2

Umnova, O., Attenborough, K., Shin, H.-C., \& Cummings, A. (2005). Deduction of tortuosity and porosity from acoustic reflection and transmission measurements on thick samples of rigid-porous materials. Applied Acoustics, 66(6), 607-624.

https://doi.org/10.1016/j.apacoust.2004.02.005

Zare, P., Sheikhi Narani, S., Abbaspour, M., Fahimifar, A., Mohammad Hosseini, S. M. M., \& Zare, P. (2020). Experimental investigation of non-stabilized and cementstabilized rammed earth reinforcement by Waste Tire Textile Fibers (WTTFs). Construction and Building Materials, 260, 120432.

https://doi.org/10.1016/j.conbuildmat.2020.120432

\section{INVESTIGATION OF SOUND ABSORPTION OF UNTREATED TYRE TEXTILE FIBRE WASTE}

\author{
R. Ružickij, R. Grubliauskas
}

Summary

Rubber granules and metal fiber are successfully reused in tyre recycling, but waste tyre textile fibre (WTTF) is a significant problem. Researchers are conducting research into the use of tyre textile fibre waste for thermal insulation, where its potential is visible. Because thermal insulation has a close relationship with sound absorption, it is believed that WTTF is also suitable for use in indoor noise reduction. The experiment method is based on ISO 10534-2, which would determine the sound absorption coefficient $\alpha$ of a material by applying an impedance tube. The results obtained in the study showed that WTTF waste has good sound absorption properties, the sound absorption coefficient at low frequencies $250-500 \mathrm{~Hz}$ was $0.06-0.52$, and at higher frequencies $1000-1600 \mathrm{~Hz}$, the absorption coefficient varied $0.44-0.94$. The use of this material would be a great alternative to the traditional mineral fiber materials currently in use.

Keywords: fibrous sound absorbing materials, sound absorption coefficient, tyre waste. 